\title{
The Sullivan Approach to Horizontal Restraints
}

\author{
Thomas E. Kauper†
}

In considering antitrust law's treatment of horizontal restraints "then" and "now," I am tempted to say that we began with United States v. Addyston Pipe \& Steel Co. ${ }^{1}$ in 1898, we are back to Addyston Pipe in 1987, and all the false starts in between have been for naught. We have not gone in a straight line, as Professor Sullivan suggests, ${ }^{2}$ but in a circle, or by some other geometrical pattern that has taken us back to the starting point. Unfortunately, the problem is not quite so simple. The basic "naked-ancillary" restraint distinction drawn in Addyston Pipe is not the final analysis but a starting point, albeit a fundamental one. ${ }^{3}$

In the search for standards synthesizing what Professor Sullivan describes as "self-executing" rules, ${ }^{4}$ on the one hand, and virtually unbridled discretion, on the other, the law is focusing on what Addyston Pipe left unanswered. Courts are attempting to structure antitrust analysis in a way that takes into account a wide variety of factors, confines judicial discretion to acceptable levels, and leads to generally acceptable outcomes. $^{5}$ I believe that while "self-executing" (or per se) rules may have a place, their role is limited to the relatively ferw cases in which we are confident both about the characterization such rules require, and about the generalizations upon which they are predicated. In other words, per se rules are legitimate if, and only if, the conduct they prohibit is generally anticompetitive (however we may define it) and presents little oppor-

$\dagger$ Henry M. Butzel Professor of Law, University of Michigan. A.B. 1957, J.D. 1960, University of Michigan.

1. 85 F. 271 (6th Cir. 1898) (Taft, J.), modified and aff'd, 175 U.S. 211 (1899) (setting forth the "naked-ancillary" restraint distinction). (1987).

2. Sullivan, The Viability of the Current Law on Horizontal Restraints, 75 CALIF. L. REv. 835

3. This distinction has been described by Judge Robert Bork as "central to modern antitrust." R. Bork, The ANTITRUst Paradox 28 (1978). Bork characterizes Judge Taft's opinion in Addyston Pipe "as one of the greatest, if not the greatest, antitrust opinions in the history of the law." Id. at 26.

4. Sullivan, supra note 2 , at 842 .

5. A good deal of current commentary is directed toward the development of a "truncated" rule of reason analysis. See, e.g., 7 P. AREeda, ANTITrust Law 427-36 (1986) (discussing the collapse of reasonableness and per se analysis in recent cases). Compare Easterbrook, The Limits of Antitrust, 63 TEX. L. REV. 1, 14-39 (1984) (presenting a set of filters designed to combine per se and rule of reason analysis) with Markovits, The Limits to Simplifying Antitrust: A Reply to Professor Easterbrook, 63 TEX. L. REv. 41, 76-86 (1984) (criticizing Easterbrook's filters). 
tunity for the creation of efficiency. ${ }^{6}$ In all other cases, the examination must focus on these issues directly.

But how is this examination to be conducted? Is there a logical progression of inquiry, so that the judicial process goes in stages and stops when proof fails at a given stage? When can we generalize sufficiently in order to use what may be described as "evidentiary shortcuts"? To be more specific, when is a market power screen necessary or appropriate? How is a court to quantify and balance efficiency gains against losses attributable to adverse output and price effects (if a court is to balance such factors at all)? When, if ever, should conduct that promotes efficiency while also increasing market power be condemned because there are less restrictive means available to the same end? At what stages in the inquiry should a court ask these questions?

Professor Sullivan raises these same questions, and they underscore his analysis of the Supreme Court's horizontal restraint cases of the past decade. He is surely correct in describing the evolving standards as "the implosion of rule of reason and per se analysis-of discretion and selfexecuting rule." 7 As a necessary corollary, courts have moved sharply away from specific rules predicated on conduct characterizations and away from outcomes based on pigeonholing certain activity. But courts continue to search for a structured middle ground, for modified per se rules or a method of "truncated rule of reason" analysis, ${ }^{8}$ using some or all of the variables just described.

I

\section{The Relevance of Disagreements over Values, INSTITUTIONAL CONCERNS, AND ECONOMIC ANALYSIS IN HORIZONTAL RESTRAINT CASES}

The range of disagreement concerning the present Court's treatment of horizontal restraints is relatively small. A few would contest the simple, classic per se rules that condemn hardcore price fixing and naked horizontal territorial restrictions without further inquiry into market power, purpose, or actual effect. ${ }^{9}$ Most of us, however, find these rules

6. See, e.g., Broadcast Music, Inc. v. Columbia Broadcasting Sys., 441 U.S. 1, 9 (1979) (per se rules apply where practice is "plainly anticompetitive" or "without 'redeeming virtue' "); Continental T.V., Inc. v. GTE Sylvania, Inc., 433 U.S. 36, $49-50$ (1977) (per se rules apply where conduct is "manifestly" anticompetitive).

7. Sullivan, supra note 2 , at 842 .

8. Id. at 845 .

9. For the most extreme criticisms, see D. ARmentano, ANTITRUST AND Monopoly: ANatomy of A Policy Fallure 133-62 (1982); Smith, Why Not Abolish Antitrust?. 7 REgulation Jan.-Feb. 1983, at 23. Critics of per se rules do not question the allocative inefficiencies such cartel activities may cause, but rather believe that such effects cannot long endure, 
both appropriate and a solid base upon which to build. There is, in short, a consensus that horizontal restraints can restrict output and increase price and those doing so should be condemned.

Nevertheless, basic disagreements over antitrust policy still exist. These disagreements, however, have far more to do with the basic policy concerning vertical restraints than with the fundamental propositions underlying horizonal restraints. In the area of vertical restraints, the issue is whether there is reason to condemn such restraints at all (at least in the absence of significant adverse horizontal effects). ${ }^{10}$ In the area of horizontal restraints, the basic condemnatory consensus is clear.

The controversy over vertical restraints differs in another respect from the minimal controversy over horizontal restraints. Critics of contemporary vertical restraint rules have no precedent base from which to start." There is little in "received law" to anchor their position. Horizontal restraints are another matter. The boundaries of discussion are set by Standard Oil Co. v. United States, ${ }^{12}$ which contains a somewhat different synthesis derived from United States v. Addyston Pipe \& Steel Co. ${ }^{13}$ A good deal of the undesirable underbrush that has grown up over the intervening years has been eliminated by several recent Supreme Court decisions ${ }^{14}$ and a new superstructure is coming into place. Commenta-

or object to the size of cases that such rules encourage enforcement agencies and private plaintiffs to bring. See, e.g., R. POSNER, ANTITRUST LAW $39-55$ (1976) (discussing the fragility of cartels and characterizing some current per se cases as negligible in effect); Dialogue: Are Economists Taking Over?, in Changing Antitrust STandards 31 (Conference Bd. Research Bull. No. 144, 1983) (Professor Yale Brozen commenting that "as long as [collusive] arrangements do not bar entry in some way, we do not need to worry about consumer welfare").

10. Compare Easterbrook, Vertical Arrangements and the Rule of Reason, 53 ANTiTRUST L.J. 135 (1984) (calling for elimination of vertical restraints from serious antitrust scrutiny) and Posner, The Next Step in the Antitrust Treatment of Restricted Distribution: Per Se Legality, 48 U. CH1. L. REV. 6 (1981) (calling for characterization of distributional restrictions as "per se legal") with Pitofsky, In Defense of Discounters: The No-Frills Case for a Per Se Rule Against Vertical Price Fixing, 71 GEo. L.J. 1487 (1983) (justifying per se treatment of vertical price fixing).

11. The Supreme Court's initial foray into the vertical restraints area, Dr. Miles Medical Co. v. John D. Park \& Sons Co., 220 U.S. 373 (1911), is still the focus of most of the discussion.

12. 221 U.S. 1 (1911).

13. 85 F. 271 (6th. Cir. 1898), modified and aff'd, 175 U.S. 211 (1899).

14. NCAA v. Board of Regents, 468 U.S. 85 (1984), is significant both for its refusal to condemn the NCAA's college television plan as per se illegal and for its contribution to the development of a new analytical methodology. See Sullivan, supra note 2, at 847-54. Broadcast Music, Inc. v. Columbia Broadcasting Sys., 441 U.S. 1 (1979), rejected a simple characterization analysis, thereby casting doubts on prior decisions which relied on overly simplistic characterizations, most notably United States v. Topco Assocs., 405 U.S. 596 (1972). National Soc'y. of Professional Eng'rs. v. United States, 435 U.S. 679 (1978), significantly curtailed the range of factors to be considered in horizontal restraint cases, departing markedly from Chicago Bd. of Trade v. United States, 246 U.S. 23I, 238 (1918). Arizona v. Maricopa County Medical Soc'y., 457 U.S. 332 (1982) is somewhat problematic. The Court there held that horizontal maximum price fixing was unlawful, but only after finding no significant integration of the competitors' operations and finding less restrictive means available for achieving the parties' ends. While the outcome may be criticized, the methodology is consistent with Broadcast Music. 
tors are thus less concerned with the basic approach than with particular elements of horizontal restraint analysis, and precedent plays a significant role in the debate.

\section{A. Values}

Finding the correct analytical methodology in horizontal restraint cases depends upon defining the ultimate question we seek to answer. If we cannot agree on why we value competition, we cannot agree on what constitutes competitive harm. Undeniably, strong differences of opinion exist on the goals of antitrust, and evaluation of both outcomes and methods may depend on the values held by the evaluator. ${ }^{15}$ The Chicago school focuses exclusively on allocative efficiency. ${ }^{16}$ Their sole concern is the restriction of output and increase in price brought about by enhanced market power. Others, Professor Sullivan included, believe that antitrust is multipurposed, encompassing concerns ranging from wealth distribution to political and social freedom. ${ }^{17}$ Some have greater faith in the efficacy of government intervention in the marketplace than others. $^{18}$ Judicial discretion raises questions of democratic rule to

15. For a description of the variation in views, see Kauper, The Goals of United States Antitrust Policy-the Current Debate, 136 ZEITSChRIFT FÜ DIE GESAMTE STAATSWISSENSCHAFT 408 (1980) (article in English). The debate over goals has raged in the literature. Compare 1 P. AREEDA \& D.TURNER, ANTITRUST LAW III 103-113 (1978) (hailing “efficiency" goals over "populist" goals) and R. BORK, supra note 3, at $81-89$ ("consumer welfare" should be the "exclusive goal") and Baxter, Responding to the Reaction: The Draftman's View, 71 CAL.1F. L. REV. 618, 619-21 (1983) (also advocating "consumer welfare" goals) and compare Easterbrook, Is There a Ratchet in Antitrust Law?, 60 TEx. L. REv. 705, 714-17 (1982) (espousing economic goals) with Fox, The Modernization of Antitrust: A New Equilibrium, 66 CORNELL L. REv. 1140, 1146-55 (1981) (questioning efficiency as the sole goal) and Pitofsky, The Political Content of Antitrust, 127 U. PA. L. REv. 1051, 1052-58 (1979) (calling for broad inquiries which include "political" goals) and Sullivan, Economics and More Humanistic Disciplines: What are the Sources of Wisdom for Antitrust?, 125 U. PA. L. REV. 1214, 1232-41 (1977) ("humanistic" goals more "fully illuminate" antitrust issues).

16. See, e.g., R. BoRK, supra note 3, at 81-89; Baxter, supra note 15, at 619-21; Gerhart, The Supreme Court and Antitrust Analysis: The (Near) Triumph of the Chicago Scliool, 1982 SuP. Cr. REv. 319, 320-22. See generally Posner, The Chicago School of Antitrust Analysis, 127 U. PA. L. REV. 925 (1979) (discussing the emergence of Chicago and its apparent convergence with the "Harvard" school).

17. See, e.g., Fox, supra note 15 , at $1176-90$ (describing the desirable equilibrium betwcen efficiency and nonefficiency goals); Sullivan, supra note 15, at 1232-41 (discussing the role of philosophy and history in antitrust analysis); Sullivan, Antitrust, Microeconomics and Politics: Reflections on Some Recent Relationships, 68 CALIF. L. REV. 1 (1980) (finding economic analysis useful as one tool among many).

18. Compare Easterbrook, Comparative Advantage and Antitrust Law, 75 CALIF. L. REV. 983 (1987) (courts possess a "comparative advantage" over the market only in cases of naked cartels and large mergers with serious entry barriers) and Easterbrook, Workable Antitrust Policy, $84 \mathrm{MiCH}$. L. REV. 1696, 1700-02 (1986) (government cannot identify the best structure of a market) with Fox, Consumer Beware Chicago, 84 MiCH. L. REv. 1714, 1718-19 (1986) (private power is just as worrisome as government power) and Sullivan, supra note 17, at 5.8 (finding the virtue of "minimum levels of welfare" in the regulatory state). 
some, ${ }^{19}$ but not to others. These value differences all bear significantly on analysis of antitrust rules and methodologies because the assessment of outcomes depends on the evaluation of starting premises. ${ }^{20}$

But do antitrust value differences have a significant impact on the analysis of horizontal restraints? The answer is yes, but not in very many cases, certainly not enough to frustrate development of a generalized method of analysis upon which most lawyers can agree.

There are two major goals in horizontal restraint analysis that engender widespread agreement: the minimization of negative market power effects and the maximization of productive efficiencies. First, negative market power effects such as output reductions and corresponding price increases have been the primary harm identified with horizontal restraints from the beginning. ${ }^{21}$ Professor Sullivan agrees, although he correctly notes the disagreement over why these effects have been the priniary concern. ${ }^{22}$ History does not clearly indicate whether the fear has been allocative inefficiency or wealth transfer from consumers to monopolists. ${ }^{23}$ Second, the creation of productive efficiencies is, and with a few deviations has always been, a major goal in the protection of the conpetitive process in the analysis of horizontal restraints. ${ }^{24}$ If a variety of other values are built into the protection of competition, how will these values relate to the treatment of horizontal restraints?

Some observers continue to express the view that competition includes concerns over the deniocratic process as well as a variety of other "quality of life" values. ${ }^{25}$ But Professor Sullivan's analysis makes nothing of such other values. Nor, unless size alone is a concern, is it apparent how they are relevant as an independent matter. Economic power in particular markets has little to do with fear of political or social

19. See, e.g., R. BoRK, supra note 3, at 89-93.

20. Professor Sullivan notes all of this and, describing himself as "conservative" and "conventional," suggests an analysis based on "the text and context of [antitrust's] earlier authoritative articulations." Sullivan, supra note 2, at 836 . This leaves his own value system somewhat unclear, although in subsequent analysis he identifies the particular circumstances when he is prepared to look beyond allocative efficiency concerns. Id. at 853 .

21. See Standard Oil Co. v. United States, 221 U.S. 1, 52-60 (1911).

22. See Sullivan, supra note 2, at 839-41.

23. Compare Bork, Legislative Intent and the Policy of the Sherman Act, 9 J.L. \& ECoN. 7 (1966) (legislative history shows that the primary concern of the Sherman Act was efficiency) with Lande, Wealth Transfers as the Original and Primary Concern of Antitrust: The Efficiency Interpretation Challenged, 34 HASTINGS L.J. 65 (1982) (dominant legislative purpose was avoidance of wealth transfer from consumers to monopolists). The implications of these different emphases are discussed in detail in Hovenkamp, Antitrust Policy After Chicago, 84 MiCH. L. REv. 213 (1985) (ultimately predicting shifts away from the Chicago model).

24. This was a primary concern in the formulation of the "naked-ancillary" distinction in United States v. Addyston Pipe \& Steel Co., 85 F. 271 (6th Cir. 1898), modified and aff'd, 175 U.S. 211 (1899).

25. See, e.g., Sullivan, supra note 2 , at $841 \&$ n.30. 
power, or a simple preference for small units or local control of business. Issues related to income distribution may be relevant, in the sense that we object to market power because of its distributional effects. But if the "distributional effects" are simply transfers of wealth from consumers to monopolists, such effects are seldom of concern absent market power, or conduct creating market power. They are virtually irrelevant as an independent matter.

In discussing specific future problems, Professor Sullivan does not incorporate an independent concern over distributional effects. He does, however, consider concerns over the intimidation of competitors by predatory acts, the stifling of entry, and the coercion that requires or precludes particular market conduct. According to Sullivan, these are concerns to which antitrust has always responded. ${ }^{26}$ But are these concerns, which Professor Sullivan describes as "related" to the goal of allocative efficiency, actually independent of, or inconsistent with, that goal? In other words, would the incorporation of these values into antitrust policy move antitrust's treatment of horizontal restraints in a direction away from the Chicago School's preoccupation with allocative efficiency? The answer turns, in part, on what these concerns are meant to encompass.

On its face, prohibiting predatory acts that lead to a significant increase in market power is consistent with the Chicago approach. ${ }^{27}$ If Professor Sullivan is concerned about something called "predation" that does not have market power effects, it is indeed a free-standing concern. He does not suggest, however, that this is the case. Much the same may be said about stifling entry. There is a place in an efficiency-directed antitrust policy for consideration of entry barriers and entry-threatening conduct, although many in the Chicago School find "true" entry barriers few and far between. ${ }^{28}$

"Coercion" is a much more difficult element to analyze. In some cases, coercion is nothing more than the use of established market power

26. Id. at 853 .

27. There may be considerable agreement that predatory pricing is not likely to be tried, and even less likely to be successful. See Matsushita Elec. Indus. Co. v. Zenith Radio Corp., 106 S. Ct. $1348,1357-58$ (1986) and authorities cited therein. There is considerable disagreement in the extensive literature attempting to define it. For a brief summary, see P. AREEDA, ANTITrust Analysis: Problems, Texts, Cases 190-203 (3d ed. 1981). But if truly predatory pricing does occur, even Chicagoans agree that the effect is adverse. See, e.g., R. POSNER, supra note 9, at 184-96; Easterbrook, Predatory Strategies and Counterstrategies, 48 U. CHI. L. REV. 263, 265-76 (1981). Professor Easterbrook suggests that an offense of predation "should be forgotten," because it is neither likely to occur nor to be costly if it does, because the risk of error is too great, and because the other costs of intervention are too high. Id. at 337 . He does not assert that if true predation did in fact occur the effect would not be anticompetitive in the Chicago sense.

28. See R. BORK, supra note 3, at 310-29; R. POSNER, supra note 9, at 92-93, 186-87; Posner, supra note 16 , at $945-48$. 
that further increases that power. Concern over such "coercion" is consistent with the goal of efficiency. But Professor Sullivan means something more, faulting the Chicago theorists for failing to give "coercion" independent weight. ${ }^{29}$ Sullivan's idea of "coercion" remains vague, and I am not certain that we can give it a general meaning beyond "knowing it when we see it." I am certain, however, that coercion or denial of opportunity are rarely involved in horizontal cases where there is no enhancement of market power. In other words, it is generally irrelevant in cases where giving it weight would point in a direction away from allocative efficiency. ${ }^{30}$

There are policies other than those suggested by Professor Sullivan which, if included in antitrust analysis, would mark a inore dramatic departure from the economic efficiency model. For example, were antitrust used to transfer wealth from large producers to small ones (as opposed to assuring that wealth is not transferred from consumers to monopolists), productive efficiencies might become irrelevant. ${ }^{31}$ The emphasis might then shift away froin market power altogether. Those who seek an economy of small producers for "quality of life" or political reasons might oppose virtually all agreements among competitors (although some might prefer various loose-knit integrations as a way of forestalling more permanent alliances). ${ }^{32}$

The values apparently urged by Professor Sullivan, however, are not so extreme; they all bear some relation to market power. For the most part, then, the multivalued approach he espouses, with which I emotionally agree, leads in the same direction as single-minded emphasis on economic efficiency. The relevant range of disagreement over values, therefore, is not so great as to preclude development of a method of analysis in horizontal restraint cases with which most can agree. ${ }^{33}$

Despite the narrow range of disagreement, value differences between the Chicago School and a variety of others could occasionally affect outcomes as particular elements of analysis are put at issue. Assume, for

29. See Sullivan, supra note 2 , at $852-54$.

30. For a fuller discussion of coercion in these cases, see infra notes $77-84$ and accompanying text.

31. The best known judicial statements of this position are in Brown Shoe Co. v. United States, 370 U.S. 294, 344 (1962) and United States v. Aluminum Co. of Am., 148 F.2d 416, 429 (2d Cir. 1945).

32. See, e.g., Standard Oil Co. v. United States, 337 U.S. 293, 319-20 (1949) (opinion of Douglas, J.). Justice Douglas voted to uphold a series of requirements contracts between a major petroleum company and independent service station operators precisely because he feared that unless the contracts were upheld, the firm would integrate forward, a result which in his judgment would have been even worse.

33. I do not mean that differences in value orientation are irrelevant to the analysis of horizontal restraints. As noted above, coercion, for example, has no place in allocative efficiency analysis unless it refers to the use of market power in ways which increase it. 
example, a horizontal restraint that demonstrably restricts output while simultaneously increasing productive efficiency. If the adverse output effects outweigh the efficiency gains, the conduct should be condemned. But weighing requires quantification. If the only cognizable adverse effect is the output that the monopolist does not produce (the "dead weight loss"), it is likely to be small and thus easily overbalanced by small productive efficiency gains. However, if wealth transfers from consumers to producers are also taken into account, the balance may be weighed quite differently, depending in part on the extent to which cost reductions are shared with consumers. The balance may be further shifted if rent-chasing costs and $x$-inefficiencies are considered. ${ }^{34}$ Additional values might come into play where adverse effects and efficiency gains are evenly balanced (or where proof of neither is satisfactory). In such cases, coercion or some other value might tip the scale (the so-called "tie-breaker"). ${ }^{35}$

A second case where values rejected by the Chicago school may be appropriate exists when a situation produces no allocative inefficiencies (or at least none are proven in the Chicago sense), but creates some productive efficiencies. Some might assert that the productive efficiencies should be ignored if other values are thwarted by the conduct. ${ }^{36}$ Professor Sullivan does not go so far, nor would I. And there is no indication that the courts are prepared to do so, at least in horizontal restraint cases.

In the final analysis, the area in which other policies may be relevant to the disposition of horizontal cases is, in my view, relatively small. Applications of other policies are confined primarily to those horizontal restraints that involve a degree of integration (restraints other than "naked" in the Addyston Pipe sense) in which the balance between

34. Rent-chasing refers to resources expended in efforts to protect or extend a monopoly position. Some of these expenditures confer no advantage on consumers (or confer an advantage smaller than the amount expended) and may be viewed as a social cost. See R. POSNER, supra note 9, at 11-14; Posner, The Social Costs of Monopoly and Regulation, 83 J. PoL. ECON. 807 (1975). $X-$ inefficiencies result when firms not facing significant competitive pressure tolerate higher costs. See F. Scherer, Industrial MARket Structure ANd EConomic Performance 464-66 (2d ed. 1980). If monopolists tolerate such waste, their higher costs may be viewed as a further cost of monopoly.

35. See Pitofsky, supra note 15, at 1067 n.44 (suggesting "political concerns" as a possible tiebreaker). Truly "even" cases are rare, because we are unlikely to ever know enough (even if we know what we are looking for) to be confident of an even balance. The case where we believe both adverse allocative and beneficial productive efficiencies are present, but available information is inadequate to draw a balance, is much more likely. Judgment in such a case might usefully be informed by other values.

36. This was suggested, for example, in Brown Shoe, 370 U.S. at 334-46. See Kauper, The "Warren Court" and the Antitrust Laws: Of Economics, Populism, and Cynicism, 67 MicH. L. REV. $325,329-34$ (1968) (discussing the Warren Court's impact on antitrust values). 
adverse market power effects and productive efficiency gains is either even or unclear. Truly "naked" restraints remain easy to deal with.

\section{B. Institutional Concerns}

Like most other areas of the law, antitrust policy is an amalgam of substantive values and institutional concerns. Choices between judicial discretion and rules reflect judgments about the appropriate role of the judiciary in a democratic society. The same concern over separation of powers principles that drives much of the strict constructionism in constitutional interpretation leads to calls for removal of judicial discretion in antitrust matters. Some have contended that antitrust must focus on the single value of economic efficiency because the balancing of multiple values is a legislative function. ${ }^{37}$ Such arguments have been bolstered by references to legislative intent in an attempt to establish that a multivalued approach is inconsistent with Congress's purpose in enacting the antitrust laws. ${ }^{38}$ Others may perceive both the legislative intent and the role of courts quite differently. ${ }^{39}$

Furthermore, as Professor Sullivan notes, no necessary correlation exists between views held on substantive values and views held on institutional issues. ${ }^{40}$ The disagreement over these matters runs far beyond antitrust law, and beliefs about them are even more deeply held than those about the substance of antitrust. The Supreme Court's movement away from free-wheeling rule of reason analysis and toward a more structured inquiry ${ }^{41}$ has diminished some of the criticism of judicial discretion. However, a move too far in the direction of a rigid, highly structured analysis may invite attack from those who see a more activist role for courts and those who perceive that the legislative purpose was to encompass a wide range of values.

Similarly, views about antitrust rest in part on perceptions about the relative efficacy of markets and governments as economic regulators. ${ }^{42}$ If markets are thought to be effective in most cases, and able to correct themselves when not, government intervention is seldom warranted. If, in addition, government is often unwise, tlie case against government directed "correction," whether in the form of antitrust or other market regulation, is even stronger. Perceptions about markets and regulation

37. See, e.g., R. BORK, supra note 3 , at $82-84$.

38. See, e.g., Bork, supra note 23.

39. See, eg., Fox, The Battle for the Soul of Antitrust, 75 CALlF. L. REv. 917 (1987).

40. Sullivan, supra note 2 , at 841 .

41. See, e.g., Broadcast Music, Inc. v. Columbia Broadcasting System, 441 U.S. 1 (1979). But see Arizona v. Maricopa County Medical Soc'y, 457 U.S. 332 (1982). Maricopa has been criticized as a step back from the Court's gradual acceptance of Chicago efficiency theories. Gerhart, supra note 16 , at $319-20$.

42. See sources cited supra note 18 . 
are seldom provable. They are to a substantial degree a matter of faith. Nonetheless, these biases are critical in the shaping of antitrust. For example, if one believes that markets will usually do a better job of correcting their failures than the government, intervention should occur only in those cases where the market clearly cannot correct the adverse effects within a reasonable time. Consequently, such beliefs carry a very strong presumption against government action. Conversely, the burden of proof on issues relating to increases in productive efficiency should be easily satisfied. The resulting rule would only find antitrust violations on clear proof of adverse allocative effects that the market is unlikely to correct, and then only if productive efficiencies cannot possibly be created. In a world of imperfect knowledge, antitrust intervention would be rare indeed.

\section{Economic Analysis}

The final area of disagreement concerns the analytic tools to be used in making the economic analysis called for in horizontal restraint cases. To the Chicago School, there is a single tool, often described as "neoclassical price theory," to be used in all antitrust cases. This theory predicts when adverse allocative effects are likely to occur, and is therefore used to formulate general rules and shape factual inquiries. But even some who agree with the Chicago School's beliefs about goals criticize exclusive reliance on the neoclassical model, arguing that because the model is static, it fails to account for a variety of relevant external factors. ${ }^{43}$ Others have faulted the model for failing to adequately recognize the relevance of strategic behavior. ${ }^{44}$ While valid, these criticisms should not lead to a complete rejection of the Chicago mode of analysis, at least with respect to horizontal restraints. Critics faulting Chicago for ignoring strategic behavior and the effects of externalities have not attacked the neoclassical views about cartel behavior, views consistent with those far predating Chicago.

The Chicago emphasis on price theory is not an outright rejection of the utility of structural analysis, even though Chicago theorists may reject some of its broader implications. For example, Chicagoans do not accept the view that, absent overt collusion, highly concentrated industries will necessarily perform in a manner similar to a cartel. But they do recognize the relevance of concentration and market shares. Concentration facilitates collusion, which in turn can lead to adverse output effects. High market share is indicative of the ability to exercise market power

43. See Hovenkamp, supra note 23 , at $244,255-60$ for a summary and illustrations of these criticisms. For a Chicago School response, see Easterbrook, supra note 18.

44. For a discussion and summary of these criticisms, see Hovenkamp, supra note 23, at 260 . 83. 
through collusion, and therefore presumptions based on high market shares can be consistent with the Chicago model. ${ }^{45}$

Judges must make decisions about which tools of economic analysis they will use, and their choices may significantly affect outcomes. Nowhere is this more clear than in Matsushita Electric Industrial Co. v. Zenith Radio Corp. ${ }^{46}$ where the Court relied to an extraordinary degree on neoclassical price theory to resolve ambiguities in evidence concerning alleged predation (although even here there is no indication that the Court would have used price theory to override unambiguous proof of predation). Furthermore, an uncritical acceptance of the Chicago dichotomy between conduct that increases profits through increased market power and conduct that increases profits by lowering costs-and the conclusion that conduct that does not do the former must do the latter ${ }^{47}$-may affect case outcomes. Failure to prove output restriction may become proof of productive efficiency.

But here again we must inquire about the relevance of disputes over the appropriate method of economic analysis to the development of a more structured legal analysis in horizontal restraint cases. Groups of competitors will only infrequently engage in strategic conduct, such as predatory pricing or spending designed to raise rivals' costs. Strategic conduct is more commonly at issue in evaluating single-firm behavior, although cases of collaborative strategic conduct can be imagined. ${ }^{48}$ In his discussion of future horizontal restraint problems, Professor Sullivan does not rely on such concepts. ${ }^{49}$ As he suggests, it is perhaps more relevant to recognize the static nature of the Chicago model, and then go beyond this model to consider the impact on the market of a variety of externalities. The model is based on consumer preferences reflected in the dollars they spend, and thus gives no weight to other things consumers value, but for which they see no reason individually to pay, such as freedom from pollution. I question, however, whether such considera-

45. See, e.g., R. Bork, supra note 3, at 263-79 (discussing use of market share analysis in horizontal restraint cases); R. PoSNER, supra note 9, at 55-71 (discussing use of market share and concentration ratio analysis in collusion and merger cases).

46. 106 S. Ct. 1348 (1986).

47. See, for example, the opinion of Judge Bork in Rothery Storage \& Van Co. v. Atlas Van Lines, Inc., 792 F.2d 210, 221 (D.C. Cir. 1986) stating: "If it is clear that [defendants] by eliminating competition among themselves are not attempting to restrict industry output, then their agreement must be designed to make the conduct of their business more effective. No third possibility suggests itself." But Judge Bork does recognize as a third possibility that a firm may seek to increase profits "by some device not related to either productive or allocative efficiency, such as taking a bookkeeping advantage of some wrinkle in the tax laws". R. BORK, supra note 3, at 122. This third possibility would rarely, if ever, be at issue in antitrust litigation.

48. Group strategic behavior was alleged in Matsushita, $106 \mathrm{~S}$. Ct. at 1349, but generally speaking, the literature on predation and raising rivals' costs deals with single-firm behavior. See Hovenkamp, supra note 23 , at 260-283 for a typical discussion.

49. Sullivan, supra note 2 , at $860-90$. 
tions will be significant in most horizontal restraint cases. Cases involving externalities are few in number. Even fewer are those that point in a policy direction other than that suggested by consideration of price and output effects.

Disputes over policy goals, institutional concerns, and the appropriate method of economic analysis will continue for years to come. There are no immutable truths to be "discovered," so we may expect antitrust rules and structures to continue to change. In recent years, the Supreme Court's reformulations of antitrust standards have moved towards consensus $^{50}$ and broad consensus concerning horizontal restraints now exists. Nevertheless, the lack of consensus over goals, institutional concerns, and the appropriate economic analytical tools is real. But with the significant exceptions discussed below, the lack of consensus ought not impede the development of a structure of analysis in horizontal restraint cases. In other words, the courts should be able to develop Professor Sullivan's "synthesis" without full resolution of all these disagreements.

The Court has never made firm ideological commitments in antitrust cases, there is no reason to think it will now, and there is no reason to think it should. The "truth" changes too often. Its "synthesis" must remain flexible enough to accommodate areas of fundamental policy disagreement. For now, the primary focus will be on the effect of horizontal agreements on prices and output, not because this is the exclusive concern of antitrust, but because broad consensus defines it as antitrust's primary concern. Courts will not condemn conduct that creates efficiency, if for no other reasons than the existing political climate and the threats to domestic firms from foreign competition. ${ }^{51}$

50. For example, the Court has vigorously reasserted its long-standing per se rule against naked horizontal price fixing. E.g., Catalano, Inc. v. Target Sales, Inc., 446 U.S. 643,647 (1980) (agreement among wholesalers to require retailers to pay in cash held plainly anticompetitive as essentially an agreement to eliminate discounts, and thus per se illegal without further examination under the rule of reason). Faced, however, with a strong economic consensus against the per se rule against nonprice vertical restraints adopted in United States v. Arnold, Schwinn \& Co., 388 U.S. 365, 381-82 (1967), the Court overruled Schwinn in Continental T.V., Inc. v. GTE Sylvania, Inc., 433 U.S. 36, $47-59$ (1977). The Court's opinion in Matsushita relies heavily on a stated consensus among economists that predatory pricing is by nature speculative. $106 \mathrm{~S}$. Ct. at 1357-60. On the other hand, the Court has been unwilling to reject the long-standing per se rule against vertical price fixing, a subject where consensus is lacking. See California Retail Liquor Dealers Ass'n. v. Midcal Aluminum, Inc., 445 U.S. 97, 102-06 (1980).

51. This "new" synthesis has a base in precedent. Standard Oil Co. v. United States, 221 U.S. 1 (1911), provides some foundation, and United States v. Addyston Pipe \& Steel Co., 85 F. 271 (6th Cir. 1898), modified and aff'd, 175 U.S. 211 (1899) (where the synthesis is more fully developed) provides a basic structure. The Court has not established, as it has with respect to resale price maintenance, a venerable body of precedent from which it has never departed. In the horizontal restraint area, cases which deviate from the new synthesis can be dismissed as inconsistent with earlier decisions. Thus, the new synthesis cannot be said to clearly violate received law. National Soc'y of Professional Eng'rs v. United States, 435 U.S. 679 (1978), illustrates this point. In rejecting the broad rule of reason analysis set forth by Justice Brandeis in Chicago Bd. of Trade v. United 
II

\section{The Emerging Synthesis-AREAS of CONTROVERSY}

I turn now to the specific elements of the emerging synthesis between per se rules and unbridled discretion where a lack of consensus over goals, institutional concerns or appropriate economic analysis clearly is relevant. These include (1) the proof of adverse allocative effects (output restrictions and price effects), and the use of a so-called "market power screen"; (2) the use of a "less restrictive alternatives" test; (3) the relevance of "coercion"; and (4) the appropriate response to ambiguity, uncertainty of proof, and the unavailability of perfect information. ${ }^{52}$

\section{A. Proof of Market Power}

From its inception, antitrust has sought to prevent adverse output and price effects caused by horizontal restraints. ${ }^{53}$ Does this mean that such adverse effects must be proved directly? In some cases this may be possible. But a requirement that adverse output effects be directly established on a case-by-case basis is inconsistent with history ${ }^{54}$ and is economically unjustified. ${ }^{55}$ To require direct proof would often mean that truly anticompetitive acts escape condemnation. Full information is often unavailable, and perceptions about actual effects are clouded by the presence of a variety of external factors that may have influenced prices and outputs. ${ }^{56}$

States, 246 U.S. 231 (1918), the Court returned to the focus on purely competitive effects espoused in Standard Oil, 221 U.S. at 49-62. Its unwillingness to tolerate justifications based upon the necessary but socially bad effects of competition traces back as far as United States v. Trans-Missouri Freight Ass'n, 166 U.S. 290 (1897). Continental T.V., Inc. v. GTE Sylvania, Inc., 433 U.S. 36 (1977), is another good example. Its overruling of United States v. Arnold, Schwinn \& Co., 388 U.S. 365 (1967), was subjected to virtually no criticism on the ground that it ignorned "received law," in part because it was consistent with the earlier White Motor Co. v. United States, 372 U.S. 253 (1963).

52. I will leave detailed discussion of the specific hypotheticals in Part II of Professor Sullivan's article to another day. He has correctly identified the structural changes in the American economy which will drive analysis for years to come. For the most part, his analysis is in economic efficiency terms and poses no significant substantive "value" questions. This alone suggests that in horizontal situations the debate over values is relevant to a relatively discrete group of cases.

53. See supra text accompanying notes 21-23.

54. As far back as Standard Oil Co. V. United States, 221 U.S. 1 (1911), the Court stressed that in some cases the "nature and character of the contracts" may create "a conclusive presumption" of illegality. Id. at 65 . In other words, no proof of actual effect is necessary where certain conduct is proven. See also United States v. Trenton Potteries Co., 273 U.S. 392, 395-402 (1927) (power and purpose to fix prices establishes antitrust violation without examination of actual price effects).

55. Thus where a restraint has no purpose other than restricting ouput and raising prices, there is no need as an economic matter to examine whether it actually did so. See R. BoRk, supra note 3 , at 267-68. Even Chicagoans concede that the necessary effect of monopoly power, in the absence of efficiencies, is to restrict output and increase prices. See R. PoSNER, supra note 9, at 9-10.

56. See, e.g., United States v. Socony-Vacuum Oil Co., 310 U.S. 150, 208-10 (1940) (price 
Moreover, antitrust prohibitions predicated upon direct proof of adverse price and output effects may have less deterrent effect than rules based upon inferences drawn from conduct and market power. My own experience suggests, for example, that businessmen almost invariably assume that what they do has little or no market effect-or, at least, assume their lawyers will be able to show that this is the case. Clarity facilitates deterrence. Requiring proof of actual market effects may reduce clarity and, thereby, reduce the deterrence of conduct likely to have such effects.

In a number of cases, courts can infer adverse effects from other facts. The per se rules applicable to horizontal price fixing and territorial allocation rest on a presumption of adverse effects that is in turn based on a theory predicting such allocatively inefficient consequences from such conduct. With truly naked restraints, there is no reason to proceed otherwise. Where no significant efficiencies are present, inferences concerning output and price effects can be drawn from conduct alone.

However, where the restraint accompanies some form of integration $^{57}$ likely to generate real efficiencies, the issue becomes more difficult. Purpose is a less reliable indicator, but direct proof of adverse price and output effects may be even more difficult. Efficiencies complicate the measurement of price and output effects. The effects may occur gradually, complicating "before and after" analysis. Conduct that has such effects may escape condemnation simply because of failures in information. The surrogate for direct proof has traditionally been market power, and increases in that power brought about by the restraint. Chicago theorists often draw such inferences. ${ }^{58}$ In most cases involving integration then, proof of market power and its relationship to the challenged conduct (a relationship that may be established through economic theory) is necessary to establish adverse price and output effects. ${ }^{59}$ Consequently,

increases allegedly attributable, at least in part, to new control of crude oil production by states, federal control of "hot oil" pursuant to the Connally Act, and a sharp increase in demand); American Column \& Lumber Co. v. United States, 257 U.S. 377, 378 (1921) (where the argument was made that price increases during the period the restraint was in effect were caused by "low stocks" resulting from inactivity during World War I, by the "breaking loose" of pent-up demand thereafter, and by abnormal rainfall in the South and Southwest).

57. See, e.g., NCAA v. Board of Regents, 468 U.S. 85 (1984); Broadeast Music, Inc. v. Columbia Broadcasting System, 441 U.S. 1 (1979). The integration accompanying the horizontal restraint was less clear in Arizona v. Maricopa County Medical Soc'y, 457 U.S. 332 (1982).

58. The Chicago argument is as follows: Absenee of market power makes any output restrictions unlikely. Proof that market power is significantly increased is therefore an indication that output restriction could occur. At some level of market power then, restriction of output must be presumed. See, e.g., R. POSNER, supra note 9, at 112. But market share does not necessarily mean market power in this sense. If conduct is truly output restricting, sales and in some cases market share might be expected to fall, all other things being equal. See Easterbrook, supra note 5, at 31-33.

59. One caveat should be added. If, in a given case, adverse price and output effects must be 
market definition, market share, and other structural analyses will generally be at the heart of these cases. ${ }^{60}$

Does it follow that in a horizontal restraint case not subject to a per se rule, proof of market power should be the first step in a truncated rule of reason inquiry, such that failure to pass through the screen terminates the case? Professor Sullivan's analysis suggests that the answer is "yes" in some cases and "no" in others. Apparently, he would require at least some showing of power where the conduct in question "display[s] no helpful relationship to competition on the merits," $"$ where it fails to produce either efficiency or product or market development. This suggests that in cases involving some element of integration, courts should first address the question of efficiency. If no efficiencies are present (or, Sullivan would probably add, if they are available through a less restrictive means) proof of market power is not essential.

The difficulty with this screening approach is that while it may convince us that no significant efficiencies are involved, it does not provide us with any basis for concluding that adverse price and output effects are present. Professor Sullivan is not prepared to assume their presence merely from the failure of proof on efficiencies, since such an assumption would reflect the same "either output restrictmg or efficiency creating" attitude for which he criticizes the Chicago school. Clearly, Professor Sullivan is concerned with more than merely the order in which issues should be addressed, however, for he asserts that in some cases where conduct is coercive and not significantly efficient, market power need not be established at all. ${ }^{62}$ His assertion that freedom from coercion is a freestanding value is in direct conflict with Chicago analysis, and highlights a critical issue of fundamental disagreement. ${ }^{63}$

Professor Sullivan suggests that the Supreme Court has adopted his analysis in NCAA v. Board of Regents. ${ }^{64}$ The Court did indicate that proof of market power was not a prerequisite to a finding of illegality ${ }^{65}$ But, rightly or wrongly, the NCAA Court found that output restriction had been directly established. ${ }^{66}$ With such a showing, proof of market power was not necessary. Moreover, in finding that the NCAA violated

quantified in order to compare them with efficiency gains, actual proof of them may be required. This is a good reason for believing that a precise weighing cannot be expected.

60. Of course, market shares are but a rough estimate of proof of market power, even assuming that markets are properly defined. At best, high market shares afford a basis for presuming market power. But courts will undoubtedly continue to use such estimates until they can be convinced that market power can be better determined in some other way.

61. Sullivan, supra note 2 , at $848-49$.

62. Id. at 849.

63. See infra text accompanying notes 77-81.

64. 468 U.S. 85 (1984). See Sullivan, supra note 2, at 851.

65. See 468 U.S. at 109-10.

66. Id. at 106-07. 
the Sherman Act, the Court certainly did not find that the NCAA had no market power. Professor Sullivan's analysis actually finds greater support in FTC v. Indiana Federation of Dentists. ${ }^{67}$ The Court there asserted that proof of market power is unnecessary where anticompetitive effects are found in the refusal to compete over one element of a product package. ${ }^{68}$ But the Court came perilously close to characterizing the restraint as "naked."69 The decision does not, therefore, unambiguously support the Sullivan position.

The issue of whether we need to establish market power sharply raises the disagreements over the substantive goals of antitrust. If one assumes that output restriction and adverse price effects are the focus of inquiry, should we require a showing that defendants have a significant market share before allowing the case to proceed further? In other words, is such a market share screen appropriate? If market share is an adequate surrogate for market power, use of such a screen might be effective. But this is not the case. Power can be proven in a variety of ways. In some instances, power may be inferred from the conduct itself, ${ }^{70}$ or from the purpose of the restraint. ${ }^{71}$ After all, the issue is power rather than market share. A market power screen, as opposed to a market share screen, is thus appropriate in horizontal cases where the conduct is related to some degree of integration, except where the court is prepared to incorporate some other value into antitrust doctrine. The introduction of other values complicates matters. For example, if coercion even in the absence of market power is of concern, a market power screen is inappropriate. In determining whether such a screen should be used, other values must be directly considered.

\section{B. Consideration of Less Restrictive Alternatives}

The need to evaluate "less restrictive alternatives" as part of a truncated rule of reason analysis is also a matter of some controversy. United States v. Addyston Pipe \& Steel $C_{0 .}{ }^{72}$ can be read to support such a requirement, although it need not be. ${ }^{73}$ The Supreme Court in $N C A A$,

67. 106 S. Ct. 2009 (1986).

68. Id. at 2018.

69. Id. at 2018-19.

70. For example, systematic price discrimination is strong evidence of the existence of market power. See 2 P. AREeda \& D. TURner, ANTITRust LaW 9514 (1978); R. PosNer, supra note 9 , at $62-63$.

71. For example, proof that the purpose of a restraint could be accomplished only if the firms had market power is some evidence that they believed they in fact had such power. Although not conclusive because the firms' judgment may have been wrong, it is relevant nevertheless.

72. 85 F. 271 (6th Cir. 1898), modified and aff'd, 175 U.S. 211 (1899).

73. In Addyston Pipe, the court described a legitimate ancillary restraint as one "necessary to protect the covenantee in the enjoyment of the legitimate fruits of the contract." and which does not exceed "the necessity presented by the main purpose of the contract." Id. at 282 . This description 
however, clearly rested its decision in part on the finding that any efficiencies created by the defendant's restraint need not be weighed because they could have been achieved in less restrictive ways. ${ }^{74}$

Much of the debate in this area has been clouded by the fact that the "less restrictive alternative" standard has been misunderstood. A restraint does not become anticompetitive simply because a less restrictive alternative is available. Anticompetitive effects, however defined, must be independently established before evaluation of alternatives becomes relevant. The alternatives analysis relates only to efficiencies or other justifications. In fact, the evaluation of alternatives is not necessary at all if the alleged efficiency gains are trivial. ${ }^{75}$ In the abstract then, the rejection of efficiency claims on least restrictive alternative grounds seems eminently sensible. The courts should not be required to weigh adverse output and price effects agamst efficiency gains when such gains can be obtained without the adverse effects. Society should not bear the costs of anticompetitive conduct in the name of efficiency if it can have the efficiency without the adverse competitive effects.

The evaluation of alternatives, however, is subject to two related objections. First, it makes business judgments subject to a form of second-guessing. This objection is alleviated by requiring courts to exercise reasonable judgment. Moreover, a general understanding that evaluation of alternatives is part of antitrust methodology may have the beneficial effect of pressuring firms to evaluate alternatives more closely in the first instance. But Chicago theorists carry the objection a step further. They contend that a profit-maximizing firm confronted with alternative means to the same end will always select the means that works most efficiently. Rejection by a court of the selected, and therefore inherently more efficient course of conduct, is thus inefficient. ${ }^{76}$ However, even Chicagoans recognize that profits can be enhanced both by added efficiency and by increases in market power. Thus, the choice may be motivated by mixed concerns. The alternative selected may be chosen precisely because it benefits the firm in two ways: through the efficiency created and through additions to market power. On balance, therefore, evaluation of alternatives within the limits suggested above should be a part of antitrust's methodology in cases involving integration.

may mean only that the restraint must bear a reasonable relationship to the legitimate purpose of the integration. But "necessity" may also be read to encompass an examination of less restrictive alternatives.

74. 468 U.S. $85,114-15,119$ (1984).

75. This is how the Court used alternatives analysis in NCAA, 468 U.S. at 114-15, 119.

76. See, e.g., R. BoRk, supra note 3, at 439-40. 


\section{Of "Coercion" and Other Values}

Disagreements over the need to prove market power and, to some extent, over the appropriateness of evaluating alternatives highlight the continuing debate over goals. In Professor Sullivan's analysis, "coercion" should also play a major, independent role in antitrust analysis. Coercion of competitors, customers, and even suppliers has often been a factor in antitrust analysis over the years, much to the consternation of those who advocate an efficiency-oriented policy. Coercion language has appeared most frequently in vertical restraint cases ${ }^{77}$ cases involving boycotts, ${ }^{78}$ and section 2 cases. $^{79}$ But what does "coercion" actually mean, and is it truly an independent value? Should we condemn conduct as coercive, for example, even though it creates efficiency? Is there room for coercion analysis in an efficiency-based antitrust system? This is a large topic that cannot be exhausted here, but some comments on Professor Sullivan's use of the concept are in order.

As noted earlier, ${ }^{80}$ coercion has a place in an efficiency-oriented analysis if it refers either to true predation or the use of leverage to gain power in a second market. These are instances where use of market power could result in further output restrictions. But Professor Sullivan uses coercion in a broader sense. In defining the appropriate case for per se treatment, he talks of "manifest price enhancement, output restriction, or coercive restraint of rivals." 81 Two cases he discusses, NCAA v. Board of Regents ${ }^{82}$ and a hypothetical involving two competitors who bribe a labor union to strike against a competitor, are illuminating. Professor Sullivan characterizes the NCAA's restrictions as "coercive" because they required some colleges to share the benefits of their successful football programs with those that were less successful. ${ }^{83}$ In the labor union hypothetical, he describes the conduct as blatantly anticompetitive without regard to the market power of the parties. In both cases, Professor Sullivan stresses "coercion" as a key factor of decision.

But assuming that inability of some NCAA schools to effectively

77. See, e.g., Simpson v. Union Oil Co., 377 U.S. 13, 17 (1964).

78. See, e.g., Klor's, Inc. v. Broadway-Hale Stores, 359 U.S. 207 (1959) (manufacturers boycotting retailers); Eastern States Retail Lumber Dealers' Ass'n. v. United States, 234 U.S. 600 (1914) (retailers boycotting wholesalers). See also the discussion of the criteria for applying a per se rule to boycotts in Northwest Wholesale Stationers, Inc. v. Pacific Stationery \& Printing Co., 472 U.S. $284,289-98$ (1985).

79. See, e.g., United States v. Aluminum Co. of Am., 148 F.2d 416, 429 (1945) (suggesting that a monopolist violates section 2 of the Sherman Act if it uses '"unduly' coercive means").

80. See supra text accompanying notes $29-30$.

81. Sullivan, supra note 2 , at 862 .

82. 468 U.S. 85 (1984).

83. In contrast, the Court in Broadcast Music, Inc. v. Columbia Broadcasting Sys., 441 U.S. 1 (1979), upheld the use of a blanket license in the joint marketing of copyrights, emphasizing that individual licensors remained free to act on their own. 
market their games independently was a highly relevant fact, is it "coercion" that was objectionable? Was the objection that the larger schools were coerced by the smaller ones and that such coercion was fundamentally unfair? I think not. The fact that all member colleges were bound by the plan simply made the plan easier to characterize as output restricting. ${ }^{84}$ Labeling the NCAA plan "coercive" is thus not particularly helpful to the analysis.

The labor union example is quite different, and does suggest that some conduct that seems unfair should be condemned without regard to its likely effect on prices or output. But note two things about the example. First, nothing is gained in efficiency terms, a point Professor Sullivan stresses. (The example could have posed the efficiency versus coercion issue more sharply if, by putting a competitor out of business, the conspirators could have lowered their costs through longer production runs.) Second, the conduct in question is probably illegal without regard to the antitrust laws. Where the alleged restraint involves use of tactics themselves illegal under standards external to antitrust, coercion has a more precise meaning than it does otherwise. Moreover, even if efficiency is increased, the legal system has already determined that it will not tolerate such conduct. The real issue in such cases is whether antitrust should provide an additional remedy.

I am not prepared to say that freedom from coercion has no place in antitrust. Where firms with market power use that power to enhance it, and thus further increase price and restrict output, the conduct is of antitrust concern (though I doubt that characterizing it as coercive is helpful). The problem with "coercion" is its inherent vagueness. Without definition, and without ties to market power, notions of coercion introduce considerable discretion into judicial analysis and may, through impairment of efficiency, impose costs that society is not prepared to bear.

\section{Uncertainty and Ambiguity}

We live in a world of limited information, with imperfect systems for evaluating complete information. Judges must make decisions based on what is placed before them. Even if we could agree that we should weigh adverse allocative effects against efficiency gains, this can actually be done in only a few cases. First of all, there is no agreement on what constitutes the costs of monopoly, and even if we could generally identify them, measuring those costs will be nearly always impossible. Furthermore, efficiencies are notoriously difficult to quantify. ${ }^{85}$ To compound

84. Similarly, the adverse effects of the plan in Broadcast Music would have been greater if the licensors had not remained free to act on their own.

85. See, e.g., R. Bork, supra note 3, at 126-29. But see 4 P. AREedA \& D. Turner, 
the problem, where given conduct reduces costs but also has adverse market power effects, the extent to which cost reductions are passed on to consumers may warrant evaluation. ${ }^{86}$ The treatment of uncertainty is thus critical to any method of analysis. It is a question usually resolved by lawyers in terms of burden of proof.

The use of surrogates is one solution to these difficulties. We can use market share to establish market power, and market power to establish price and output effects. Economic theory, whether neoclassical price theory or theories about strategic behavior, tells us a great deal about the likely effects of particular conduct and focuses further inquiry. But in horizontal restraint cases involving significant integration, no surrogates can balance accurately the relevant adverse and beneficial effects where such balancing is not otherwise possible. Instead, there is some room here for simple intuition. If any potential efficiencies are clearly trivial, they must simply be disregarded; conversely, where such efficiencies are clearly great, and adverse effects are small or not likely to be felt, the case should be dismissed.

This leaves the hard case where there are likely to be cost benefits and adverse allocative effects. Here disagreements over institutional concerns, which run more deeply than any of the others into antitrust, have their clearest relevance. If markets seldom fail to be self-correcting, if government is in error more often than not, these hard cases should simply be dismissed. ${ }^{87}$ Others who see markets and government processes differently might well conclude that the danger of enhanced market power justifies intervention unless the defendant clearly establishes and quantifies all cost savings. They thus use theory (or precedent) to conclude that certain conduct is likely to impair allocative efficiency and insist on strict proof of productive gains. ${ }^{88}$ Although there is a range of options in between, a solution satisfactory to all is impossible because choices in these hard cases rest more on faith than demonstrated truth. Moreover, these institutional values, real as they are, are not likely to be exposed in the judicial process, resulting in opinions that may seem irrational even though they are not.

ANTITRUST LAW II 948-960 (1980) (defining the various possible efficiencies); Williamson, Economies as an Antitrust Defense: The Welfare Tradeoffs, 58 AM. EcoN. REv. 18 (1968) (presenting an economic analysis of efficiencies and trade-offs).

86. See Sullivan, supra note 2, at 851-52.

87. See, e.g., R. BORK, supra note 3, at 133 (noting a "general preference for freedom").

88. See 4 P. AREEDA \& D. TURNER, supra note 85 , at II 948d (requiring direct proof of size economies), ITी 939-962 (discussing economies generally). Compare Antitrust Division Merger Guidelines, 47 Fed. Reg. 28,493, 28,502 (1982) with Antitrust Division Merger Guidelines, 49 Fed. Reg. 26,827, 26,834 (1984). The 1982 Guidelines state that the Department of Justice will consider efficiencies only in "extraordinary cases" because of difficulties in proof and quantification. The 1984 Guidelines, on the other hand, indicate that certain types of efficiencies will be considered where established "by clear and convincing evidence." 
Professor Sullivan does not cast his analysis in terms of burden of proof. He suggests that, where a given restraint creates both power and efficiency, the outcome should turn on whether efficiency gains are garnered in the form of monopoly profits. If so, the arrangement should be condemned. ${ }^{89}$ But this solution places heavy emphasis on distributional effects, and thus assumes the relevance of factors other than dead weight loss. It also calls for an analysis of price effects that may be too complex in a given case.

We can ask that the limits of information be pressed and that what is available be used. But when mformation fails, or becomes too complex, we can expect little more than informed intuition from the courts. Merely because this intuition will reflect deeply felt biases is no cause for alarm. It has always been so. The greater danger may come from undue rigidity in the structure of analysis, a rigidity that virtually invites paralysis through the inability of all cases to meet its demands.

\section{CONCLUSION}

The Supreme Court today is developing a structured approach to rule of reason analysis and subjecting more cases to it. Rules based on characterization of conduct are less significant than in the past. As Professor Sullivan observes, the Court has moved cautiously, cominitting itself to no single ideology or method of analysis. The structure retains, and will continue to retain, sufficient flexibility to accommodate values that continue to generate considerable disagreeinent.

This structure is not yet clear, but it is moving in the following direction. The initial inquiry is the one described by Judge Taft; namely, whether the restraint is "naked." If so, a per se rule is likely to be applied. With the recognition that a wider variety of horizontal restraints than previously thought could involve claims of efficiency, the scope of these per se rules is contracting. The broad language of United States v. Socony-Vacuum Oil Co. ${ }^{90}$ has already been modified by Broadcast Music, Inc v. Columbia Broadcasting System. ${ }^{91}$ The sweeping per se rule with respect to boycotts enunciated in Klor's Inc. v. BroadwayHale Stores ${ }^{92}$ has been fenced in by Northwest Wholesale Stationers, Inc. v. Pacific Stationery \& Printing Co. ${ }^{93}$ However, United States v. Topco Associates, Inc. ${ }^{94}$ still reinains. To the extent it applies to truly naked

89. Sullivan, supra note 2 , at 852 .

90. 310 U.S. 150 (1940) (condemning as per se illegal any combination "with the effect of raising, depressing, fixing, pegging, or stabilizing the price of a commodity").

91. 441 U.S. 1 (1979).

92. 359 U.S. 207 (1959).

93. 472 U.S. 284, 289-98 (1985).

94. 405 U.S. 596 (1972). In Topco, the Court held unlawful per se a provision in the licenses granted by a member-controlled cooperative association that assigned its members exclusive 
horizontal restraints, Topco probably will not be modified. But the application of a per se rule to the actual facts of Topco is inconsistent with the emerging synthesis. ${ }^{95}$ It is part of the underbrush to which I earlier alluded, and will likely be cleared away (despite Professor Sullivan's efforts to preserve it). ${ }^{96}$

Assuming that a per se rule is inappropriate, analysis under the rule of reason begins with a "quick look" at the conduct. This glance considers whether horizontal conduct by firms with market power could have significant adverse price and output effects. If the answer is clearly "no," the inquiry should stop. If "yes," the issue of market power must be addressed directly. This too can be done on a "quick look" basis, using conservative market definitions and market share analysis as Professor Sullivan suggests. If market shares are too small to permit an inference of power, the case should be dismissed unless (1) there is other evidence of market power or direct evidence of adverse price and output effects, or (2) the Court is prepared to incorporate other values into its analysis of anticompetitive effects.

Assuming that the case survives this second "quick look," the analysis becomes more complex. Professor Sullivan suggests that at this point the inquiry should turn directly to the proffered efficiency justifications. If it is clear that such efficiencies are trivial, or can be achieved in a less restrictive way, he suggests that the case is over. In other words, where defendants engaged in conduct that could have adverse effects without efficiency justification, he sees no reason to proceed further. I agree that efficiencies can be examined at this point. But in my scenario the inquiry does not stop here. The initial "quick look" at power and conduct is not definitive. A full-scale market structure inquiry is now required. If upon fuller examination market power is lacking, or it appears that the conduct cannot have adverse price and output effects, the case must be dismissed (assuming that these effects are the sole focus of the inquiry). If the opposite conclusion is reached, the violation is established.

Still unaddressed is the case where both adverse price and output effects and significant reductions in costs exist with reasonable certainty.

territories. The licenses granted each grocer-member the right to sell trademarked, private-label "Topco" goods. The Court held the arrangement subject to the per se rule against naked horizontal market division agreements. despite the obvious integration involved in the development of the private label.

95. In particular, the methodology of Topco-the characterization of the arrangement as a naked restraint without consideration of the integration involved-appears inconsistent with the analytical method set forth in Broadcast Music.

96. See Sullivan, supra note 2, at 885-86. Professor Sullivan suggests that the use of territorial restrictions in such a case will always fail the "less restrictive alternatives" test. This is a curious blending of per se and rule of reason analysis, and is certainly not the analysis relied upon in Topco. Nor is it self-evident that less restrictive means will in fact always be available to meet the legitimatc needs of Topco. 
The Supreme Court has not thought itself confronted with this case in its recent decisions, and nothing in Broadcast Music, Arizona v. Maricopa County Medical Society, ${ }^{97}$ or NCAA v. Board of Regents ${ }^{98}$ leads the way. Professor Sullivan suggests that if evidence indicates that prices have not been reduced along with costs (though perhaps not to the same extent), a violation should be found. In my own view, the Court will never carry the methodology this far, nor will it suggest any other way of offsetting benefits and losses. If such a case arises, the Court is unlikely to describe it as such. Instead, we may have to rely on hunches informed by the Court's biases about the efficacy of markets and government intervention. We can ask for little more.

97. 457 U.S. 332 (1982)

98. 468 U.S. 85 (1984). 
